\title{
The bitumen of Tell Brak from the Middle Uruk (c.3500 BC) to Late Bronze Age (c.I280 BC): origin and trade routes
}

\begin{abstract}
13 archaeological samples, dated from the Middle Uruk period (c.3500 BC) to the Late Bronze age (c.1280 BC), were analyzed by geochemical techniques in order to identify bitumen and to attempt to find its origin. Extracts do show that the samples are characteristic archaeological bitumens. Bitumens of Tell Brak were compared to some other archaeological asphalts, to crude oils and natural asphalts. Utilization of carbon isotopes on asphaltenes and biomarkers namely steranes and terpanes allowed us to identify two main areas of bitumen supply, Hit on one side along the Euphrate river, northern Iraq on the other side.
\end{abstract}

Keywords: bitumen, Tell Brak, origin, archaeological samples, natural asphalts, crude oils, steranes, terpanes, carbon isotopes, deuterium isotopes, asphaltenes
Volume 3 Issue 6 - 2018

Jacques Connan,' Joan Oates ${ }^{2}$

'University of Strasbourg, France

${ }^{2}$ The McDonald Institute for Archaeological Research, England

Correspondence: Jacques Connan, University of Strasbourg, 23 rue Saint-Exupéry, 64000-Pau, France,

Email connan.jacpues@orange.fr

Received: October 02, 2018 | Published: November 26, 2018

\section{Introduction}

Bitumen belongs to the list of common raw materials which has been extensively used in Mesopotamia, Elam and the Gulf until the Neolithic period (7000-6000 BC). Evidence of earlier use has been recently documented in the Syrian desert $^{1-3}$ near el Known where the bitumen-coated flint implement, dated 70000 BC (Middle Palaeolithic) have been unearthed. Since the pioneering works by Forbes, ${ }^{4}$ Marschner and Wright ${ }^{5}$ and Marchner et al. ${ }^{6}$ several studies were conducted on archaeological sites from present day Iraq, Iran and the Gulf, using efficient analytical techniques of petroleum exploration. A review, summarizing the various aspects of the use and trade of bitumen in antiquity and prehistory has been recently published. ${ }^{7,8}$ When an archaeologist find a presumed bituminous mixture, the recurrent questions that spring to his mind are: Is-it a real bituminous mixture? How much bitumen was used? What other additives were mixed with the bitumen? Where did the bitumen come from? At a particular location, were there any changes in sources of bitumen through time? Do these identified trade routes agree with other historical data, especially the geopolitical and cultural framework? This last question has been addressed with success in some well documented case histories spanning a rather large period of time and presenting a satisfactory bank of samples. Such demonstrative examples refer to case studies on Tell el 'Oueili in southern Iraq' and more recently on various archaeological sites of Bahrain. ${ }^{10} \mathrm{~A}$ complete study, recording the situation in Kuwait through time from $5000 \mathrm{BC}$ to $700 \mathrm{AD}$, is also available. ${ }^{11-14}$

At present no data have been published on archaeological sites along the Rhabur river and this study of the bituminous mixtures from Brak will be the first one in the area. The only recent study, published on archaeological bitumens of the Near East refers to results from Hacinebi along the Euphrates, at the border between Turkey and Syria. ${ }^{15,16}$ However the conclusions of these studies should be regarded with much caution for, as we will be demonstrating in this paper, the isotopic parameters used for tracing the source of the bitumen are not valid for largely obscured by mineral matrix effect. The present paper will summarise the geochemical results acquired on 13 archaeological samples from Brak and will discuss these data in the light of references issued from Northern Iraq, South-West Turkey and Hit.

\section{Archaeological samples}

13 archaeological samples presumed to be composed of various bituminous mixtures were selected for analysis. The sample set spans a rather long period of the historical record at Brak, starting with the Middle Uruk occupation, c. 3500 BC, and ending at the Late Bronze age around c.1280 BC. The basic information related to each sample is given in Table 1 with its macroscopic description which was carried out prior to any chemical investigation. The sample set covers a wide variety of sample types which are currently recorded in archaeological sites from the Middle East namely : bitumen crusts in the interior of potsherds $\left(n^{\circ} 1126\right.$, Figure 1$)$ or on the lip $\left(n^{\circ} 1224\right)$ or in the exterior of potsherd $\left(\mathrm{n}^{\circ} 1126\right.$, Figure 1$)$, bitumen coating on a wall cone which is probably a remain of glue $\left(n^{\circ} 1127\right.$, Figure 1$)$, bituminous coating of mats $\left(\mathrm{n}^{\circ} 1175\right)$ or baskets $\left(\mathrm{n}^{\circ} 1176\right)$, bituminous mixtures with numerous vegetal remains which looks like mortars ( $\mathrm{n}^{\circ} 1122$ and $\mathrm{n}^{\circ} 1123$ ), cakes of bituminous mixtures thought to be possibly stored raw material $\left(n^{\circ} 1128\right.$, Figure $\left.1 ; n^{\circ} 1125\right)$, hard bituminous mixtures with reed and possibly rope impressions (reed boats? roofs? $\mathrm{n}^{\circ} 1025$, $\left.\mathrm{n}^{\circ} 1177\right)$, hard black sealing agent $\left(\mathrm{n}^{\circ} 1026\right.$, Figure 1), bituminous mixture without obvious vegetal remains ( $\mathrm{n}^{\circ} 1125$ and $\left.\mathrm{n}^{\circ} 1124\right)$.

\section{Experimental}

The archaeological bituminous materials were studied using the same analytical scheme applied in previous studies. ${ }^{9,17}$ A detailed up-to-date flowchart with a description of each analytical technique has been presented with some examples in Connan. ${ }^{18} \mathrm{~A}$ binocular description of each sample was carried out prior to the detailed chemical analysis. In the present study a petrographical analysis was not undertaken for the samples appeared to be quite classical in regard of our past experience. After the sampling procedure which keep aliquots of check samples (see $n^{\circ} 1126$ in Fig.1), chemical analyses including screening techniques such as Rock-Eval pyrolysis and detailed investigations in particular molecular analysis of hydrocarbons and isotopic analysis of the asphaltenes were conducted. Several diagnostic molecular biomarkers especially on terpanes and isotopic criteria on asphaltenes $\left(\delta^{13} \mathrm{C}\right)$ were used to establish bitumento-bitumen and bitumen-to-crude oil correlations. 
Table I Basic information about the samples

\begin{tabular}{|c|c|c|c|c|c|c|c|c|}
\hline $\begin{array}{l}\text { Sample } \\
\text { number }\end{array}$ & Date & & $\begin{array}{l}\text { Date of } \\
\text { sampling }\end{array}$ & $\begin{array}{l}\text { Archaeological } \\
\text { references }\end{array}$ & Area, locus & $\begin{array}{l}\text { Comments on } \\
\text { period }\end{array}$ & $\begin{array}{l}\text { Sample } \\
\text { type }\end{array}$ & $\begin{array}{l}\text { Macroscopic } \\
\text { description }\end{array}$ \\
\hline & Max & Min & & & & & & \\
\hline 1128 & -3500 & & $27-05-1997$ & $\begin{array}{l}\text { A cake of bitumen } \\
\text { (in which the } \\
\text { bitumen was possibly } \\
\text { transported or } \\
\text { stored?) }\end{array}$ & TW 730 & Middle Uruk & $4 c$ & $\begin{array}{l}\text { A big lump of } \\
\text { "bitumen" with } \\
\text { wheathering cracks }\end{array}$ \\
\hline 1126 & -3400 & & & $\begin{array}{l}\text { a sherd from a } \\
\text { "flower pot" with } \\
\text { bitumen }\end{array}$ & $\begin{array}{l}\text { TW 7I0.A pit } \\
\text { contemporary } \\
\text { with the earliest } \\
\text { Late Uruk level } \\
\text { at Brak }\end{array}$ & $\begin{array}{l}\text { Early Late Uruk } \\
\text { (possibly Late } \\
\text { Middle Uruk) }\end{array}$ & $\mathrm{la}$ & $\begin{array}{l}\text { bitumen crust } \\
\text { coating the interior } \\
\text { of the sherd }\end{array}$ \\
\hline 1127 & -3200 & & & Wall cone & $\begin{array}{l}\text { probably from the } \\
\text { Eye Temple }\end{array}$ & $\begin{array}{l}\text { Late Uruk } \\
\text { (possibly later) }\end{array}$ & $\mathrm{Ib}$ & $\begin{array}{l}\text { bitumen coating on } \\
\text { one end of the wall } \\
\text { cone }\end{array}$ \\
\hline 1124 & -3200 & & $22-04-1997$ & Bitumen? & $\begin{array}{l}\text { TW } 627 . \text { A level } \\
\text { which lies at the } \\
\text { top of the Late } \\
\text { Uruk walls }\end{array}$ & $\begin{array}{l}\text { either right } \\
\text { at the end of } \\
\text { the Late Uruk } \\
\text { occupation, or } \\
\text { slightly earlier } \\
\text { than sample } \\
\text { I025 (TW 287) }\end{array}$ & $4 b$ & $\begin{array}{l}\text { hard and black } \\
\text { bituminous mixture } \\
\text { without obvious } \\
\text { vegetal remains }\end{array}$ \\
\hline 1125 & -3200 & & 30-04-1997 & "Bitumen" lump & $\begin{array}{l}\text { TW } 627 . \text { A level } \\
\text { which lies at the } \\
\text { top of the Late } \\
\text { Uruk walls }\end{array}$ & $\begin{array}{l}\text { either right } \\
\text { at the end of } \\
\text { the Late Uruk } \\
\text { occupation at } \\
\text { Brak, or slightly } \\
\text { earlier than } \\
\text { sample I025 } \\
\text { (TW 287) }\end{array}$ & $4 c$ & $\begin{array}{l}\text { bitumen mixture. } \\
\text { Extremely hard } \\
\text { rock }\end{array}$ \\
\hline 1025 & -3000 & -2900 & season 1992 & Register $n^{\circ} 5496$ & TW 287, level 8/9 & $\begin{array}{l}\text { Level } 10 \text { contains } \\
\text { Jamdat Nasr } \\
\text { pottery }\end{array}$ & $3 b$ or 5 & $\begin{array}{l}\text { Black sample } \\
\text { with numerous } \\
\text { weathering cracks } \\
\text { and reed (?) } \\
\text { impressions }\end{array}$ \\
\hline 1026 & -2900 & & season 1991 & Register $n^{\circ} 5218$ & $\begin{array}{l}\text { TW 249, in } \\
\text { "construction } \\
\text { level" for level } 6 \text {, } \\
\text { it can come from } \\
\text { earlier fill }\end{array}$ & $\begin{array}{l}\text { ED I in southern } \\
\text { Mesopotamian } \\
\text { terms but the } \\
\text { fact that the } \\
\text { bitumen was } \\
\text { incorporated } \\
\text { within the fill } \\
\text { beneath the } \\
\text { building }\end{array}$ & $3 b$ & $\begin{array}{l}\text { Hard black cake } \\
\text { with weathering } \\
\text { cracks and some } \\
\text { vegetal remains }\end{array}$ \\
\hline 1123 & -2900 & & $16-04-1997$ & $\begin{array}{l}\text { Bitumen showing a } \\
\text { reed mat impression } \\
\text { on the bottom, } \\
\text { sample } 2\end{array}$ & $\begin{array}{l}\text { TW } 605 \text {. This } \\
\text { is a level which } \\
\text { has been cut by } \\
\text { the pit TW } 605 \\
\text { (sample I) and is } \\
\text { earlier in date }\end{array}$ & $\begin{array}{l}\text { should be dated } \\
\text { around or not } \\
\text { long after } 3000 \\
\text { BC }\end{array}$ & $4 c$ or 2 & $\begin{array}{l}\text { brown mixture, } \\
\text { faily hard, with long } \\
\text { vegetal remains }\end{array}$ \\
\hline 1122 & -2900 & & $14-04-1997$ & $\begin{array}{l}\text { A large circular piece } \\
\text { of bitumen ( with } \\
\text { string impression?), } \\
\text { sample I }\end{array}$ & $\begin{array}{l}\text { TW 606. Pit } \\
\text { of early } 3 r d \\
\text { millennium date, } \\
\text { probably not far } \\
\text { in time from the } \\
\text { original sample } \\
1026 \text { from TW } \\
249\end{array}$ & $\begin{array}{l}\text { post -Jamdat } \\
\text { Nasr and pre- } \\
\text { Ninivite } 5\end{array}$ & $3 a$ & $\begin{array}{l}\text { brown sample } \\
\text { with numerous big } \\
\text { vegetal remains } \\
\text { inside }\end{array}$ \\
\hline
\end{tabular}


The bitumen of Tell Brak from the Middle Uruk (c.3500 BC) to Late Bronze Age (c. 1280 BC): origin and

Table Continued...

1175

$-2300$

$-2200$

1176

$-2300-2300$

1224

$-1950$

1177 $-1280$



Sherd

Matting impression and burnt wood
Akkadian

$\begin{array}{lll}\text { monumental } & \text { building, Room 30, Early Bronze age } 2 & \text { bituminous mat, } \\ \text { well preserved }\end{array}$

locus SS 585

room 3 in the

south building of

Late Akkadian,

area FS, locus

FS I525, one

construction level

later than sample

II 75

southern type of pottery but could possibly made in

Isin-Larsa period

or sometimes

referred as Early Ib

the north

Old Babylonian

very black surface

with numerous

vegetal remains

burnt roof

collapse in the

Mittanni Palace,

Late Bronze age

Mittanni

$4 b$

room II bitumen coating on the sherd lip, traces of bitumen in the interior

two types of sample. The type selected for analysis show imprints of vegetal remains (reeds?)
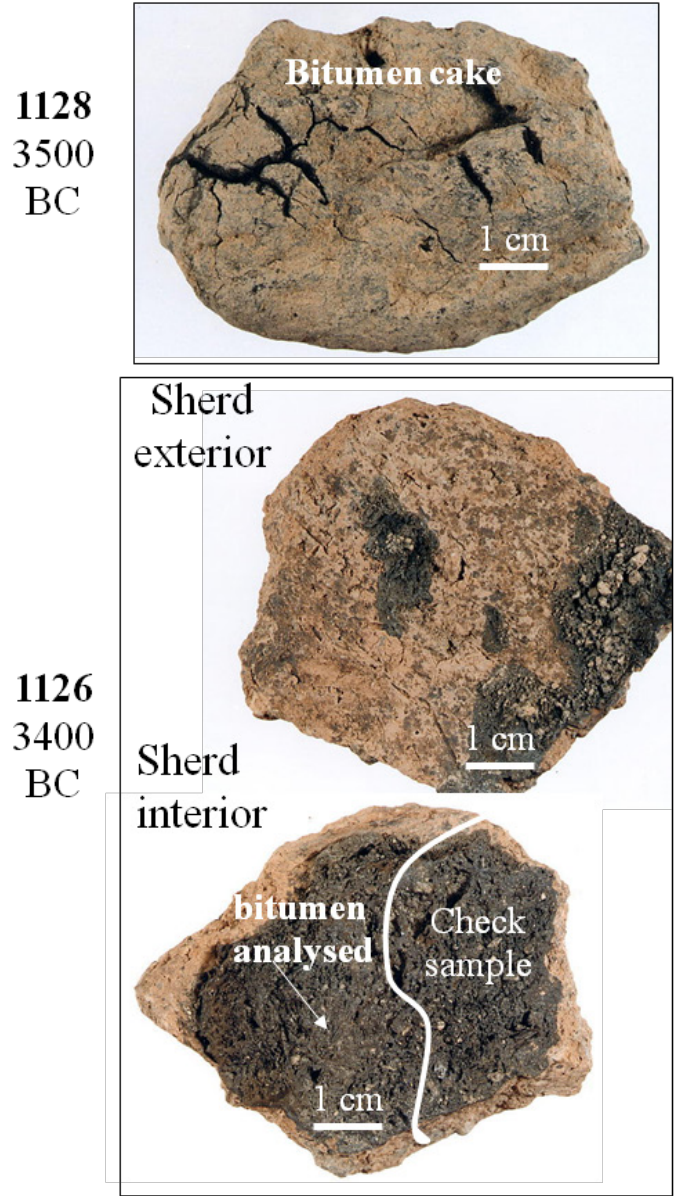

1025

3000-2900

$\mathrm{BC}$

1026

2900

$\mathrm{BC}$
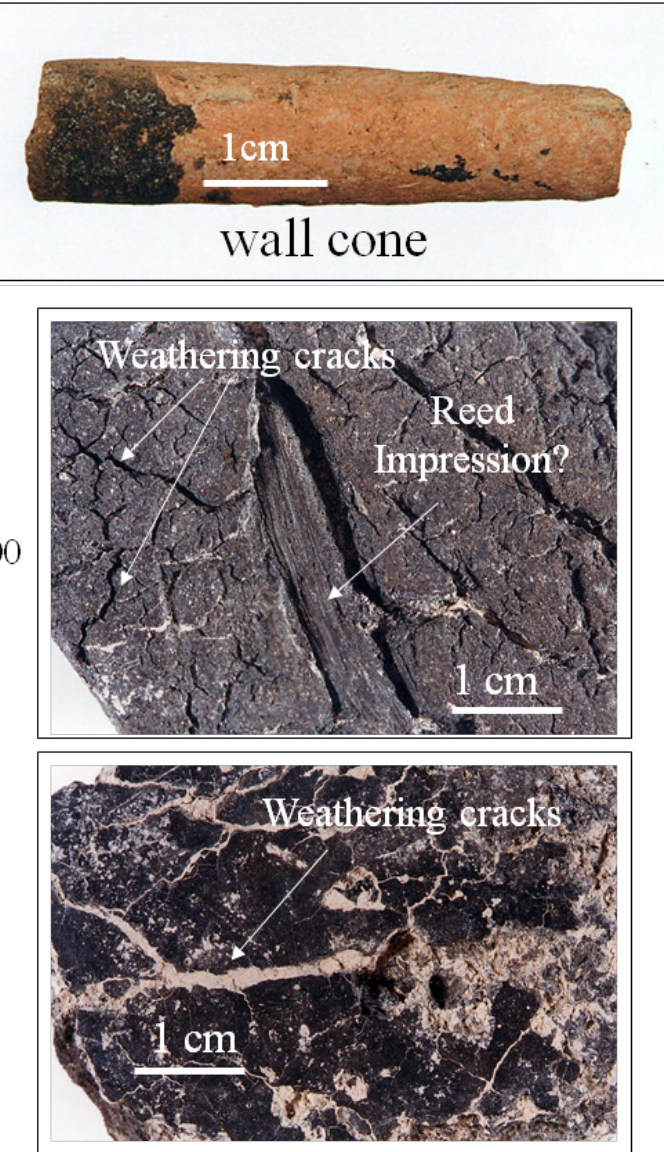

Figure I Pictures of some samples. 


\section{Results}

\section{Recognition of bituminous mixtures by Rock-Eval screening techniques of Bahrain I0}

The Rock-Eval pyrolysis of the raw samples has been applied on all samples except on samples $\mathrm{n}^{\circ} 1127,1175,1176,1224$ and 1177. The most important parameters obtained are listed in Table 2. Among the samples analysed we have not found any pure raw bitumen as identified previouly in Mashnaqa and Mari. All the samples belong to the so-called "archaeological bitumen" family, i.e. they are all bituminous mixtures processed by mixing bitumen with mineral matter and organic debris. Their TOC (Total Organic Carbon), HI (Hydrogen Index), and Tmax (temperature of the maximum of the S2 peak corresponding to Hydrocarbons released by pyrolysis) are fully consistent with the data obtained on "archaeological bitumen" of Bahrain (Figure 2). ${ }^{19}$ Obviously the sample ${ }^{\circ} 1128$, referred as a bitumen cake (Figure 1) and thought to be representative of the possible form under which the bitumen is transported, is already a manufactured sample, possibly stored to be subsequently used. One should again notice that the current bitumen richness chosen at Brak is similar to what is currently used elsewhere in the Near East: TOC are ranging from 10 to $40 \%$ as commonly observed. To summarise, the bituminous mixtures analysed at Brak are classical archaeological bitumens of the Near East.

\section{Gross composition of the dichloromethane extract}

As a follow up of the Rock-Eval screening analysis, the samples are extracted with dichloromethane and this extractable organic matter (= true bitumen) is subsequently separated into 4 fractions ( "saturates", "aromatics", "resins" and "asphaltenes") which are weighted. Gross compositions of extracts are calculated (Table 3) and represented in two classical ternary diagrams reproduced in Figure 3 \& Figure 4 All samples, except the sample 1224 which is much richer in both saturated and aromatic hydrocarbons (Figure 3), fall within the area defined as characteristics of archaeological bitumens., ${ }^{9,10}$ The sample 1224 which coats the lip of a potsherd as a thin film is much more like a natural asphalt and may have been applied as a pure material on the pottery. The low quantity recovered has not allowed us to evaluate its purity. All these basic gross composition data confirms that the extractable organic matter is bitumen which has been biodegraded and oxidised.

\section{Presumed origin of the bitumen assumed by carbon isotopic data on asphaltenes}

In previous papers, we pointed out that the carbon isotope value of asphaltenes (Table 3) (Table 4) provides reliable genetic information on crude oils and asphalts for this parameter is not significantly affected by intense weathering processes which have deeply modified the gross composition of the archaeological bitumens, leading to reduced amount of both saturates and aromatics. $\delta \mathrm{D}$ (in \%o/SMOW) of asphaltenes is not a source parameter for it was found to be very sensitive to alteration processes which have significantly modified the bitumen. This alteration entails a major shift of $\delta \mathrm{D}$ towards heavier values which means an enrichment in deuterium, as seen herein in the sample set $(-54<\delta \mathrm{D}<-77 \%$ o/SMOW, Table 3$)$. The occurrence of this heavy value range confirms what has been seen in archaeological bitumen everywhere and especially in Bahrain. Unbiodegraded crude oils, collected from reservoir at depth, do show much lighter values $(-75<\delta \mathrm{D}<-120 \%$ /SMOW $)$. Consequently heavy values are again showing that archaeological bitumens of Brak are deeply weathered oils.

$\delta^{13} \mathrm{C}$ (in \%o/VPDB) of asphaltenes from Brak have been plotted as a function of the date of samples in Figure 5. References, collected on crude oils from subsurface oil fields (Table 4) (Figure 6), natural asphalts outcropping at surface (Table 4) (Figure 6), and on natural asphalts from Hit (Figure 6), ${ }^{10}$ were incorporated in Figure 5. At a first glance, the distribution pattern of Tell Brak suggests two possible main origins for bitumen. The main source seems to be located in northern Iraq whereas the secondary one is the famous natural asphalt deposit of Hit-Abu Jir, along the Euphrates. Apparently, both sources coexist in the oldest samples, between 3500 and $3000 \mathrm{BC}$ whereas the northern source was only identified in younger samples, between 2300 and $1280 \mathrm{BC}$.

One should notice that $\delta^{13} \mathrm{C}$ values of asphaltenes recorded in both archaeological and reference samples varies between -28.3 and $-26.9 \% / \mathrm{PDB}$, i.e. within a very narrow range of less than $1.5 \%$ / PDB. These results are fully consistent with what has been reported in our previous papers,,${ }^{9,10,17,19}$ but contrast with what was published by Schwartz et al. ${ }^{15}$ These authors report $\delta^{13} \mathrm{C}$ values of so-called "archaeological bitumens", i.e. in fact raw bulk samples, between -10 and $-28 \%$ / PDB and consider these values as representative for the bitumen itself. This assumption is fully wrong for the analyses performed on the bulk raw bituminous samples do not provide reliable $\delta^{13} \mathrm{C}$ values for the total organic carbon and more precisely for its bitumen sub-fraction. In fact, this bulk measurement gives only a $\delta^{13} \mathrm{C}$ average value of the bituminous mixture which is a garbage-type sample constituted of many different components including mineral and organic ones. One should also remember that the organic matter itself is often a mixture of bitumen, vegetal debris (reed, straw) and carbonised materials from ashes. The bulk values, measured on whole samples, are consequently largely influenced by the mineral matrix present and significant shifts should be expected when carbonates are abundant. Marine carbonates possess $\delta^{13} \mathrm{C}$ values around $0^{20}$ whereas petroleum (crude oils, bitumen, natural asphalts) values cover the $-20 / 33 \%$ range. ${ }^{21}$ Occurrences of various mixtures of bitumen and minerals, especially carbonates, are obviously explaining the wide range of $\delta^{13} \mathrm{C}$ values recorded by Schwartz et al. ${ }^{15}$ in their archaeological samples of Hacinebi, Choga Mish, Ur, Farrukhabad, Gawra, Nuzi, Jerablus Tahtani, etc.

To get rid of any subsequent controversy regarding our statement, dedicated experiences were conducted to collect required demonstrative proofs. 9 samples of bituminous mixtures from Mari in which the mineral composition was determined by X-Ray diffraction were selected as test series. By chance X-Ray analyses reveal a great variety of mineralogical composition among samples with bituminous mixtures almost devoid of carbonates or carbonate-rich. On each sample we have measured the $\delta^{13} \mathrm{C}$ of the raw material as carried out by Schwartz et al. ${ }^{15}$ and the $\delta^{13} \mathrm{C}$ of asphaltenes as processed in our approach. The obtained data, gathered in Table 5, are presented in Figure 7 . The results fully confirm what was expected. First of all the $\delta^{13} \mathrm{C}$ values measured on raw samples are directly related to the amount of carbonates and especially of calcite in the present case (Figure 7A). Occurrence of large amount of calcite $\left(\delta^{13} \mathrm{C}\right.$ around 0$)$ should be shifting the bulk values towards heavier ones. This trend 
is indeed observed herein for values move from -29 to $-21 \%$ / PDB when the $\%$ of carbonates or calcite (not shown) increases. Secondly $\delta^{13} \mathrm{C}$ values of asphaltenes (Figure 7B) are independent of the mineral composition and cluster in a very narrow range which clearly indicates that the bitumen of Mari is originating from Hit. This assumption has been confirmed by molecular data on biomarkers. ${ }^{13}$ In conclusion the assessment of the origin of bitumen, carried out by Schwartz et al. ${ }^{15}$ is not substantiated by their geochemical data in particular by their isotope ones for the utilization of $\delta^{13} \mathrm{C}$ values measured on raw samples is not permitting to gather a genetic characteristic of the bitumen, necessary to find its source. By the way we must emphasized that the assessment of bitumen origin in the Near East is a difficult task for the geochemical contrasts registered among samples are falling within a narrow range as shown in Figure 5. This realty implies that the geochemical techniques applied should be very reproducible and accurate to draw conclusions on the basis of very limited variations. Clustering of data, obtained on 10 samples of Mari (Table 5) (Figure 7B) illustrates the required accuracy needed to approach the truth.

\section{Origin of bitumen based on biomarkers, isotope data on asphaltenes and biomarkers}

"Saturates" have been analysed by GC-MS in order to examine sterane $(\mathrm{m} / \mathrm{z} 217)$ and terpane $(\mathrm{m} / \mathrm{z}$ 191) patterns which are currently used to sort out some specific genetic parameters which enable to differentiate various bitumen origins. As usual in such a type of samples, biomarker fingerprints display various degrees of alteration from unaltered (state 1) to the most highly affected which is rank state 16 in our alteration scale. In the present series, 3 samples only bears very low degree of alteration (state 0 and 1 ) and most of them are belonging to the 3 to 6 state of alteration (Table 6). This result means than the $\mathrm{C}_{27}-\mathrm{C}_{29}$ steranes are generally biodegraded and show a preferential removal of $\mathrm{C}_{27}$ steranes as reported by Peters and Moldowan $^{22}$ for level 6 of biodegradation in their alteration scale. As a consequence, sterane ratios cannot be used as genetic parameters to trace the source of the bitumen. Due to the fact that terpanes do not show obvious alteration features they may be used to provide genetic parameters.

Figure 8 reproduce sterane and terpane patterns of two unaltered samples: one originates from the famous natural asphalt deposit of Hit $\left(n^{\circ} 231\right)$, in present day Iraq (Figure 6$)$, the other $\left(n^{\circ} 1128\right)$ was chosen among the Tell Brak archaeological samples. At a first glance both samples display quite similar patterns. This property is a general feature of Near East bitumens and asphalts which do not show striking differences within their molecular chemistry. To solve the enigma and try to differentiate samples, one should rely on details which are accessible by quantitative measurements of molecular ratios. Among the 65 molecular ratios which are systematically acquired, one particular ratio has been selected as fairly discriminant. It refers to $\operatorname{Tm}(17 \alpha(\mathrm{H})-22,29,30$-trisnorhopane) and Ts $(18 \alpha(\mathrm{H})-22,29,30-$ tisnorneohopane) structures which occurs with different ratios in Hit and Brak as seen in Figure 8. Due to the presumed unaltered character of most terpane patterns, this ratio may be considered as a good genetic parameter. In order to set up a classification of sample in terms of source area, a cross plot of $\delta^{13} \mathrm{C}$ of asphaltenes has been carried out with $\mathrm{Tm} / \mathrm{Ts}$ ratios (Figure 9). Figure 9 presents the data splitted into two diagrams: 9a refers to a suite of reference samples (see Fig.6 for location) in which we have gathered samples of crude oils from subsurface reservoirs (Kirkuk, Fallujah, Damir Dagh, Kilf), natural asphalts (Hit, Sari Sati, Fattah, Kifri, Zakho), bitumen veins (Harbol, Aman Hassan) as well as archaeological bitumens (Khorsabad, Niniveh, Assur, Tell es Sawwan, Telul eth Telathat, Khirbet Derak); $9 \mathrm{~b}$ presents data from Brak.

Comparison of Figures 9A \& 9B confirms the two major source areas already defined and furnish some suggestions to delineate more precise area of provenances for the bitumen in Northern Irak. The bitumen of the Hit area is well defined by oil seeps of Hit-Abu Jir and the crude oil of Fallujah 1 well at depth. Samples $n^{\circ} 1123,1124$ and 1025 of Brak belong to this genetic family. As by-product of the study, one should notice that the bitumen analysed in Khorsabad, dated from the Assyrian period, seems to be imported from Hit. This feature is consistent with the historical record. Bitumen veins of Aman Hassam (Figure 6) in Iran have not been found in the sample set. The bitumen oil seepage from the Zakho town has apparently been used in Khirbet Derak which is located at $40 \mathrm{~km}$ to the North West of Mossoul, i.e. in its neighbourhood (Table 7).

Other bitumens from Brak seems to have various origins in northern Irak, $\mathrm{n}^{\circ} 1125,1122,1128$ and 1026 may be coming from Kirkuk-Kifri oil seeps, ${ }^{23} \mathrm{n}^{\circ} 1175,1176,1177$ and 1224 , closely related to the archaeological bitumens from Telul eth Telathat, may have the same origin which is not determined yet, $n^{\circ} 1126$ has an unknown origin. In addition to analyses carried out on asphaltenes, $\delta^{13} \mathrm{C}$ of specific compounds in "saturates" were also measured using the so-called GC-C-IRMS device (Gas Chromatography-CombustionIsotope Ratio-Mass Spectrometry). In the present cases $\delta^{13} \mathrm{C}$ values of individual biomarkers may not be systematically used as genetic parameters for the recorded values may be the result of several phenomena: source, partial biodegradation of the molecule, effect of an abundant unresolved complex mixture in case of rather low concentrations. In order to select the most representative data the biomarker fingerprint were carefully examined. As a consequence we have focused on $\delta^{13} \mathrm{C}$ values of two important biomarkers, Tm

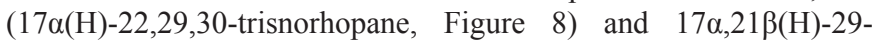
homohopane $22 \mathrm{~S}\left(\mathrm{C}_{31} \alpha \beta\right.$ HopaneS, Figure 8$)$, which are well preserved and rather abundant in all samples. The samples compared using this type of geochemical data comprise 6 samples of Brak $\left(n^{\circ} 1128,1126\right.$, $1122,1124,1025,1123), 3$ samples of Mari ( ${ }^{\circ} 96,94$ and 90 which was already referred as particular), ${ }^{13} 2$ samples of Mashnaqa $\left(n^{\circ} 563\right.$ and 554) thought to have different origins and 3 samples of Hit $\left(n^{\circ}\right.$ $231,233,235)$. The basic information on samples and the $\delta^{13} \mathrm{C}$ values on asphaltenes and biomarkers are listed in Table 8.

Plot of $\delta^{13} \mathrm{C}$ values (in \%o /PDB) of Tm and $\mathrm{C}_{31} \alpha \beta$ HopaneS as a function of $\mathrm{Tm}$ to $\mathrm{Ts}$ ratios are presented in Figure $10 \mathrm{~A} \& \mathrm{~B}$. Inside the Hit reference set up with samples $\mathrm{n}^{\circ} 231,233$ and 235, are found two samples of Mari ( $\mathrm{n}^{\circ} 96$ and 94) one sample of Mashnaqua $\left(n^{\circ} 563\right)$ and two samples of Brak (1025 and 1123). Other samples are dispersed in other area which suggests other sources. In that respect sample 1124 of Brak is not falling within the Hit area but occurs in its vicinity. One should in particular notice the location of sample $n^{\circ} 90$ from Mari which display a particular behaviour and therefore is not originating from Hit as others. This sample was previously ${ }^{13}$ identified as unique in Mari for it was the only one to contain significant amount of n-alkanes. Such a characteristic has never been seen in all natural asphalts from Hit analysed so far. 
Table 2 Rock-Eval data

\begin{tabular}{|c|c|c|c|c|c|c|c|c|c|c|}
\hline Archaeological number & Date & & SI & $\mathbf{S 2}$ & S3 & COT & Tmax & HI & IP & Ol \\
\hline & Max & Min & & & & & & & & \\
\hline 1128 & -3500 & & 27.5 & 102.25 & 6.25 & 23.55 & 427 & 434 & 0.21 & 27 \\
\hline 1126 & -3400 & & 29.74 & 251.28 & 10.89 & 42.99 & 429 & 585 & 0.11 & 25 \\
\hline 1127 & -3400 & & & & & & & & & \\
\hline 1124 & -3200 & & 17.24 & I I 4.42 & 5.16 & 22.04 & 428 & 519 & 0.13 & 23 \\
\hline 1125 & -3200 & & 16.89 & 147.96 & 6.4 & 27.7 & 430 & 534 & 0.1 & 23 \\
\hline 1025 & -3100 & -3000 & 15.86 & II5.57 & 4.57 & 24.02 & 427 & 481 & 0.12 & 19 \\
\hline 1026 & -3000 & -2900 & 8.94 & 95.84 & 4.54 & 21.7 & 431 & 442 & 0.09 & 21 \\
\hline 1123 & -3000 & -2900 & 18.8 & II 5.84 & 6 & 22.77 & 425 & 509 & 0.14 & 26 \\
\hline 1122 & -3000 & -2900 & 25.96 & 194.78 & 10.16 & 36.51 & 427 & 533 & 0.12 & 28 \\
\hline 1175 & -2300 & -2200 & & & & & & & & \\
\hline 1176 & -2300 & -2300 & & & & & & & & \\
\hline 1224 & -1950 & & & & & & & & & \\
\hline 1177 & -1280 & & & & & & & & & \\
\hline
\end{tabular}

Table 3 Gross composition of extracts and isotopic data

\begin{tabular}{|c|c|c|c|c|c|c|c|c|c|}
\hline \multirow[t]{2}{*}{ Archaeological number } & \multicolumn{2}{|l|}{ Date } & \multirow{2}{*}{$\begin{array}{l}\text { EO } \\
\text { \% /sample }\end{array}$} & \multicolumn{4}{|c|}{ Gross composition of EO } & \multicolumn{2}{|c|}{ Asphaltene isotopes } \\
\hline & Max & Min & & sat I 00 & arol 00 & res 100 & asp 100 & $\delta^{13} \mathrm{C}$ & $\delta \mathrm{D}$ \\
\hline 1128 & -3500 & & 34.93 & 3.32 & 3.4 & 14.08 & 79.2 & -27.6 & -54 \\
\hline 1126 & -3400 & & 60.7 & 1.34 & 3.29 & 20.44 & 74.93 & -27.7 & -54 \\
\hline 1127 & -3200 & & & & & & & & \\
\hline 1124 & -3200 & & 28.51 & 2.16 & 4.64 & 20.32 & 72.88 & -28.2 & -63 \\
\hline 1125 & -3200 & & 28.11 & 2.18 & 4.84 & 18.56 & 74.42 & -27.9 & -65 \\
\hline 1025 & -3000 & -2900 & 29.25 & $\mathrm{I} .45$ & 3.22 & 16.78 & 78.55 & -28 & -59 \\
\hline 1026 & -2900 & & 18.35 & 0.91 & 2.96 & $|8.4|$ & 77.72 & -27.4 & -63 \\
\hline 1123 & -2900 & & 31.52 & 1.95 & 4.13 & 16.79 & 77.13 & -28.1 & -60 \\
\hline 1122 & -2900 & & 39.13 & 2.38 & 3.81 & $|8.4|$ & 75.4 & -27.7 & -57 \\
\hline 1175 & -2300 & -2200 & 59.46 & 2.22 & 5.3 & 23.89 & 68.59 & -27.7 & -77 \\
\hline 1176 & -2300 & -2300 & 60.38 & 1.56 & 5.45 & 25.78 & 67.21 & -27.6 & -72 \\
\hline 1224 & -1950 & & & 16.57 & 21.71 & 46.28 & 15.44 & -27.5 & -59 \\
\hline 1177 & -1280 & & 50.48 & 3.65 & 4.94 & 16.12 & 75.29 & -27.6 & -62 \\
\hline
\end{tabular}

Table 4 Carbon isotope values of asphaltenes

\begin{tabular}{|c|c|c|c|c|c|c|c|c|}
\hline $\begin{array}{l}\text { Sample } \\
\text { number }\end{array}$ & $\begin{array}{l}\text { Crude oil } \\
\text { (subsurface) }\end{array}$ & $\begin{array}{l}\text { Asphalt } \\
\text { (surface) }\end{array}$ & $\begin{array}{l}\text { Name of the oil } \\
\text { field or oil seep }\end{array}$ & $\delta^{13} \mathrm{C}$ & $\begin{array}{l}\text { Average } \\
\text { value }\end{array}$ & $\begin{array}{l}\text { Standard } \\
\text { deviation }\end{array}$ & $\begin{array}{l}\text { Average } \\
\text { value }\end{array}$ & $\begin{array}{l}\text { Standard } \\
\text { deviation }\end{array}$ \\
\hline 1356 & & Oil seep & Zakho & -27.1 & & & & \\
\hline 1482 & & Oil seep & Zhako & -26.9 & & & & \\
\hline 1483 & & Oil seep & Zhako & -26.9 & & & & \\
\hline 1357 & & Oil seep & Sari Sati & -27.6 & & & & \\
\hline 1358 & & Oil seep & Quantil Bridge & -27.8 & & & & \\
\hline
\end{tabular}

Citation: Connan J, Oates J.The bitumen of Tell Brak from the Middle Uruk (c.3500 BC) to Late Bronze Age (c. I 280 BC): origin and trade routes. J His Arch \& Anthropol Sci. 2018;3(6):756-769. DOI: 10.15406/jhaas.2018.03.00163 
Table Continued...

\begin{tabular}{|c|c|c|c|c|c|c|c|c|}
\hline $\begin{array}{l}\text { Sample } \\
\text { number }\end{array}$ & $\begin{array}{l}\text { Crude oil } \\
\text { (subsurface) }\end{array}$ & $\begin{array}{l}\text { Asphalt } \\
\text { (surface) }\end{array}$ & $\begin{array}{l}\text { Name of the oil } \\
\text { field or oil seep }\end{array}$ & $\delta^{13} \mathrm{C}$ & $\begin{array}{l}\text { Average } \\
\text { value }\end{array}$ & $\begin{array}{l}\text { Standard } \\
\text { deviation }\end{array}$ & $\begin{array}{l}\text { Average } \\
\text { value }\end{array}$ & $\begin{array}{l}\text { Standard } \\
\text { deviation }\end{array}$ \\
\hline & & & & & -27.3 & 0.4 & & \\
\hline 185 & & Oil seep & Fattah I & -27.8 & & & & \\
\hline 186 & & Oil seep & Fattah 2 & -27.8 & & & & \\
\hline 187 & & Oil seep & Fattah 3 & -27.5 & & & & \\
\hline 188 & & Oil seep & Fattah 3B & -28 & & & & \\
\hline 209 & & Oil seep & Kifri & -27.7 & & & & \\
\hline 210 & & Oil seep & Kifri & -27.5 & & & & \\
\hline \multirow[t]{3}{*}{211} & & Oil seep & Kifri & -27.6 & & & & \\
\hline & & & & & -27.5 & 0.3 & & \\
\hline & & & & & & & -27.5 & 0.4 \\
\hline 690 & Oil field & & Damir Dagh & -27.4 & & & & \\
\hline 614 & Oil field & & Jambur-Bai Hassan & -27.5 & & & & \\
\hline 688 & Oil field & & Bai Hassan & -27.1 & & & & \\
\hline 1353 & Oil field & & Bai Hassan 13 & -27.8 & & & & \\
\hline 687 & Oil field & & Kirkuk I30 & -27.7 & & & & \\
\hline \multirow[t]{2}{*}{1355} & Oil field & & Kirkuk I3I & -27.7 & & & & \\
\hline & & & & & -27.7 & 0.2 & & \\
\hline
\end{tabular}

Table 5 Isotopic data on whole sample, asphaltenes and mineralogical composition of samples from Mari

\begin{tabular}{|c|c|c|c|c|c|c|c|c|c|c|c|}
\hline \multirow[t]{2}{*}{$\begin{array}{l}\text { Archaeological } \\
\text { number }\end{array}$} & \multirow[t]{2}{*}{$\begin{array}{l}\text { Archaeological } \\
\text { Campaign }\end{array}$} & \multirow[t]{2}{*}{$\begin{array}{l}\text { Average } \\
\text { date }\end{array}$} & \multicolumn{2}{|c|}{ Asphaltenes } & \multicolumn{2}{|c|}{ Whole sample } & \multicolumn{5}{|c|}{$\begin{array}{l}\text { Mineralogical composition (X-Ray diffraction } \\
\text { analysis) }\end{array}$} \\
\hline & & & $\delta^{13} \mathrm{C}$ & $\delta \mathrm{D}$ & \%carbon & $\delta^{13} \mathrm{C}$ & $\begin{array}{l}\text { quartz } \\
\%\end{array}$ & $\begin{array}{l}\text { calcite } \\
\%\end{array}$ & $\begin{array}{l}\text { dolomite } \\
\%\end{array}$ & $\underset{\%}{\text { gypsum }}$ & $\begin{array}{l}\text { felspars } \\
\%\end{array}$ \\
\hline 92 & Mari 87 & -2400 & -28.3 & -62 & 38 & -27.2 & 8 & 38 & 2 & 1 & 2 \\
\hline 97 & Mari 87 & -2330 & -28.3 & -56 & 25 & -22.5 & 11 & 46 & 10 & 1 & 5 \\
\hline 102 & Mari 87 & -2330 & -28.2 & -49 & 32 & -23.9 & 5 & 57 & 3 & 1 & 1 \\
\hline 89 & Mari 87 & -2100 & -28 & -60 & 24 & -22.5 & 6 & 60 & 7 & 1 & I \\
\hline 90 & Mari 87 & -2100 & -28.3 & -67 & 20 & -28.3 & 96 & 0 & 0 & 0 & 1 \\
\hline 99 & Mari 87 & -2100 & -28 & $-7 \mid$ & 27 & -23.2 & 9 & 44 & 8 & 1 & 1 \\
\hline 100 & Mari 87 & -2050 & -28.2 & -78 & 44 & -27.8 & 7 & 35 & I & 4 & I \\
\hline 94 & Mari 87 & -1750 & -28.2 & -59 & 23 & -26.5 & 56 & 11 & 1 & 0 & 3 \\
\hline 96 & Mari 87 & -1750 & -28 & -69 & 40 & -25.4 & 9 & 41 & 5 & 1 & I \\
\hline 98 & Mari 87 & -1750 & -28.1 & -47 & 25 & -23.6 & 6 & 36 & 4 & 0 & 3 \\
\hline
\end{tabular}

Table 6 Steranes and terpanes : state of alteration

\begin{tabular}{|c|c|c|c|c|c|c|c|c|c|}
\hline $\begin{array}{l}\text { Archae- } \\
\text { ological }\end{array}$ & Date & & $\begin{array}{l}\text { Degree of } \\
\text { alteration }\end{array}$ & Steranes & & & Diasteranes & Terpanes & \\
\hline & $\operatorname{Max}$ & Min & $\begin{array}{l}\text { Steranes } \\
\text { and } \\
\text { terpanes }\end{array}$ & $\mathrm{C} 2 \mathrm{I}-\mathrm{C} 22$ & C27- C29 &  & & $\begin{array}{l}\text { Tricyclo- } \\
\text { polyprenanes }\end{array}$ & $\begin{array}{l}\text { C27- C35 } \\
\text { hopanes }\end{array}$ \\
\hline 1128 & -3500 & & 3 & present & no alteration & & absent & present & no alteration \\
\hline 1126 & -3400 & & 12 & present & altered -no C27 & $\alpha \alpha \alpha \mathrm{R}$ altered & absent & present & no alteration \\
\hline 1127 & -3200 & & I & present & no alteration & & present & present & no alteration \\
\hline 1124 & -3200 & & 11 & present & altered -no C27 & & absent & low-present & no alteration \\
\hline
\end{tabular}


Table Continued..

\begin{tabular}{|c|c|c|c|c|c|c|c|c|c|}
\hline $\begin{array}{l}\text { Archae- } \\
\text { ological } \\
\text { number }\end{array}$ & Date & & $\begin{array}{l}\text { Degree of } \\
\text { alteration }\end{array}$ & Steranes & & & Diasteranes & Terpanes & \\
\hline 1125 & -3200 & & 13 & present-alter? & $\begin{array}{l}\text { altered-almost no } \\
\text { C27 }\end{array}$ & & absent & low-altered & no alteration \\
\hline 1025 & -3000 & -2900 & 7 & present & altered-less C27 & & absent & low-present & no alteration \\
\hline 1026 & -2900 & & 14 & absent & altered-less C27 & $\alpha \alpha \alpha \mathrm{R}$ altered & traces & absent & no alteration \\
\hline 1123 & -2900 & & 7 & present & $\begin{array}{l}\text { altered-almost no } \\
\text { C27 }\end{array}$ & & absent & low-present & no alteration \\
\hline 1122 & -2900 & & $\mathrm{II}$ & present & altered-less C27 & & absent & present & no alteration \\
\hline 1175 & -2300 & -2200 & 13 & $\begin{array}{l}\text { altered- } \\
\text { present }\end{array}$ & altered-no C27 & & absent & traces & no alteration \\
\hline 1176 & -2300 & -2300 & 13 & $\begin{array}{l}\text { altered- } \\
\text { present }\end{array}$ & altered-no C27 & & absent & traces & no alteration \\
\hline 1224 & -1950 & & 7 & no alteration & altered-less C27 & & present & low-present & no alteration \\
\hline 1177 & -1280 & & 3 & no alteration & no alteration & & present & low-present & no alteration \\
\hline
\end{tabular}

Table $7 \delta^{13} \mathrm{C}$ and $\delta \mathrm{D}$ of asphaltenes, Ts/Tm ratio of various samples : natural asphalts, crude oils and archaeological samples.

\begin{tabular}{|c|c|c|c|c|c|c|c|c|c|}
\hline \multirow{2}{*}{$\begin{array}{l}\text { Sample } \\
\text { Type }\end{array}$} & \multicolumn{2}{|c|}{ Archaeological } & \multicolumn{3}{|c|}{ Date for archaeological samples } & \multirow{2}{*}{$\begin{array}{l}\begin{array}{l}\text { Steranes and } \\
\text { terpanes }\end{array} \\
\text { Alteration type }\end{array}$} & \multicolumn{2}{|c|}{ Asphaltenes } & \multirow{2}{*}{$\begin{array}{l}\text { Tp I } \\
\text { Ts/Tm }\end{array}$} \\
\hline & Number & Location & Maxi & Average & Mini & & $\delta^{13} \mathrm{C}$ & $\delta \mathrm{D}$ & \\
\hline & 16 & Hit & & & & I & -28.2 & -73 & 0.18 \\
\hline \multirow[t]{2}{*}{ Natural } & |35-| & Abu Jir & & & & I & -28.3 & -87 & 0.11 \\
\hline & $135-2$ & Abu Jir & & & & I & -28.3 & -87 & 0.13 \\
\hline \multirow[t]{3}{*}{ Asphalt } & 231 & Hit & & & & I & -28.3 & -93 & 0.1 \\
\hline & 232 & Hit & & & & I & -28.3 & -90 & 0.13 \\
\hline & 695 & Kilf & & & & I & -28 & -85 & 0.42 \\
\hline Crude & 1352 & Kilf & & & & I & -28 & & 0.41 \\
\hline \multirow[t]{3}{*}{ oil } & 694 & Fallujah & & & & I & -28.2 & -76 & 0.14 \\
\hline & $135 \mid$ & Fallujah & & & & I & -28.2 & & 0.13 \\
\hline & 1356 & Zakho & & & & I & -27.1 & & 0.63 \\
\hline Natural & 1357 & Sara Sati & & & & I & -27.6 & & 0.12 \\
\hline asphalts & 443 & Harbol & & & & I & -27.5 & -79 & 0.06 \\
\hline and & 185 & Fattah I & & & & I & -27.8 & -102 & 0.16 \\
\hline bitumen & 186 & Fattah2 & & & & II & -27.8 & -99 & 0.17 \\
\hline \multirow[t]{4}{*}{ veins } & 188 & Fattah 4 & & & & I & -28 & -103 & 0.09 \\
\hline & 209 & Kifri & & & & I & -27.7 & -83 & 0.27 \\
\hline & 1388 & Telul Eth-Thalathat & -4500 & -4350 & -4200 & 7 & -27.6 & $-7 \mid$ & 0.18 \\
\hline & 1389 & Telul Eth-Thalathat & -4500 & -4350 & -4200 & 9 & & & 0.16 \\
\hline \multirow[t]{2}{*}{ Archaeological } & 1390 & Telul Eth-Thalathat & -4500 & -4350 & -4200 & 13 & -27.5 & -71 & 0.18 \\
\hline & 66 & Khorsabad & -800 & -750 & -700 & & -28.3 & -58 & 0.1 \\
\hline \multirow[t]{6}{*}{ samples } & 513 & Khirbet Derak & & -4500 & & $13-15$ & -27.1 & -65 & 0.63 \\
\hline & 174 & Tell es Sawwan & -5500 & -4750 & -5000 & 13 & -27.7 & -56 & 0.32 \\
\hline & 175 & Tell es Sawwan & -5500 & -4750 & -5000 & 14 & -27.9 & -58 & 0.3 \\
\hline & 225 & Niniveh & & $?$ & & 14 & -27.7 & -64 & 0.28 \\
\hline & 226 & Assur & & $?$ & & 13 & -27.7 & -55 & 0.27 \\
\hline & 1454 & Harbol & & & & I & & & 0.05 \\
\hline
\end{tabular}


The bitumen of Tell Brak from the Middle Uruk (c.3500 BC) to Late Bronze Age (c. 1280 BC): origin and

Table Continued...

\begin{tabular}{|c|c|c|c|c|c|}
\hline \multirow[t]{5}{*}{$\begin{array}{l}\text { natural Asphalts } \\
\text { and bitumen veins }\end{array}$} & 1482 & Zhako & & & \\
\hline & 1483 & Zhako & & & \\
\hline & 1099 & Aman Hassan & & & \\
\hline & 687 & Kirkuk II7 & & & \\
\hline & 1348 & Kirkuk II7 & & & \\
\hline \multirow[t]{2}{*}{ Crude } & 1354 & Kirkuk I30 & & & \\
\hline & 1355 & Kirkuk |3I & & & \\
\hline oils & 690 & Damir Dagh & & & \\
\hline \multirow[t]{5}{*}{ (oil fields) } & 1349 & Damir Dagh & & & \\
\hline & 1350 & Bai Hassan & & & \\
\hline & 1353 & Bai Hassan I3 & & & \\
\hline & 1128 & & & -3500 & \\
\hline & 1126 & & & -3400 & \\
\hline \multirow[t]{3}{*}{ Archhjaeological } & 1127 & & & -3200 & \\
\hline & 1124 & Tell & & -3200 & \\
\hline & 1125 & & & -3200 & \\
\hline \multirow[t]{8}{*}{ samples } & 1025 & Brak & -3000 & -2950 & -2900 \\
\hline & 1026 & & & -2900 & \\
\hline & 1123 & & & -2900 & \\
\hline & 1122 & & & -2900 & \\
\hline & 1175 & & -2300 & -2250 & -2200 \\
\hline & 1176 & & & -2300 & \\
\hline & 1224 & & & -1950 & \\
\hline & 1177 & & & -1280 & \\
\hline
\end{tabular}

$\begin{array}{lll}-26.9 & -86 & 0.66 \\ -26.9 & -92 & 0.66 \\ -28.5 & -101 & 0.17 \\ -27.3 & -65 & 0.43 \\ -27.3 & & 0.4 \\ -27.7 & -82 & 0.31 \\ -27.7 & -77 & 0.29 \\ -27.4 & -77 & 0.29 \\ -27.4 & & 0.26 \\ -27.1 & & 0.2 \\ -27.8 & & 0.17 \\ -27.6 & -54 & 0.36 \\ -27.7 & -54 & 0.54 \\ & & 0.27 \\ -28.2 & -63 & 0.14 \\ -27.9 & -65 & 0.24 \\ -28 & -59 & 0.15 \\ -27.4 & -63 & 0.31 \\ -28.1 & -60 & 0.14 \\ -27.7 & -57 & 0.32 \\ -27.7 & -77 & 0.16 \\ -27.6 & -72 & 0.17 \\ -27.5 & -59 & 0.17 \\ -27.6 & -62 & 0.16 \\ & & \\ & & \\ & & \end{array}$

Table $8 \delta^{13} \mathrm{C}$ of asphaltenes and some terpanes of Tell Brak, Mari, Mashnaqa and Hit.

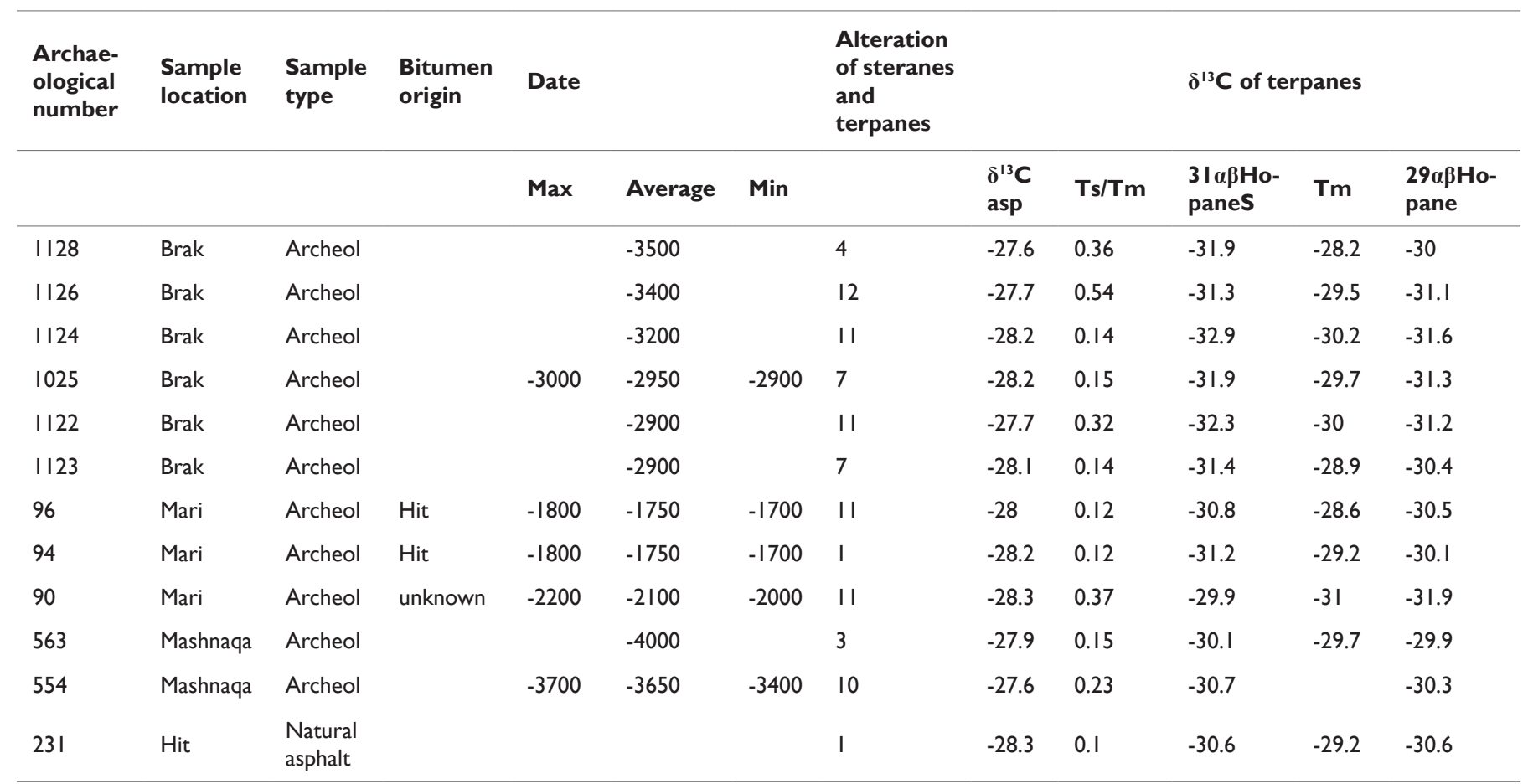


Table Continued..

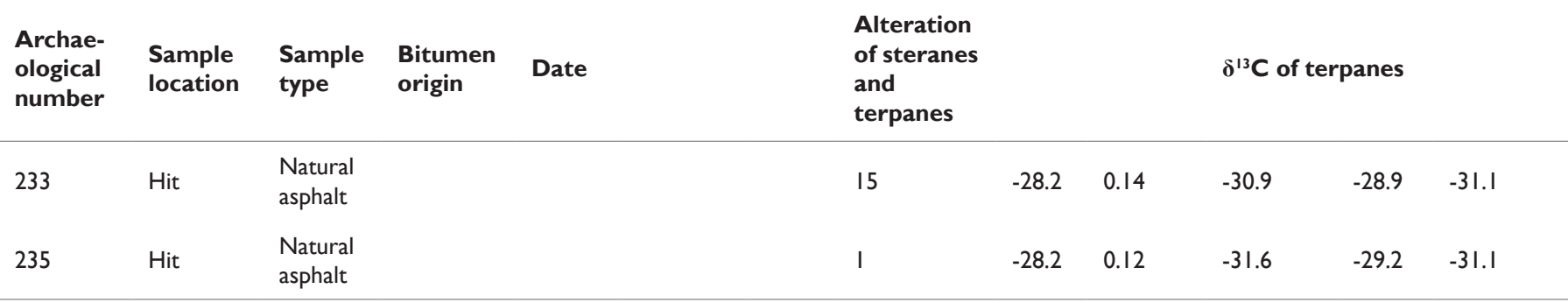

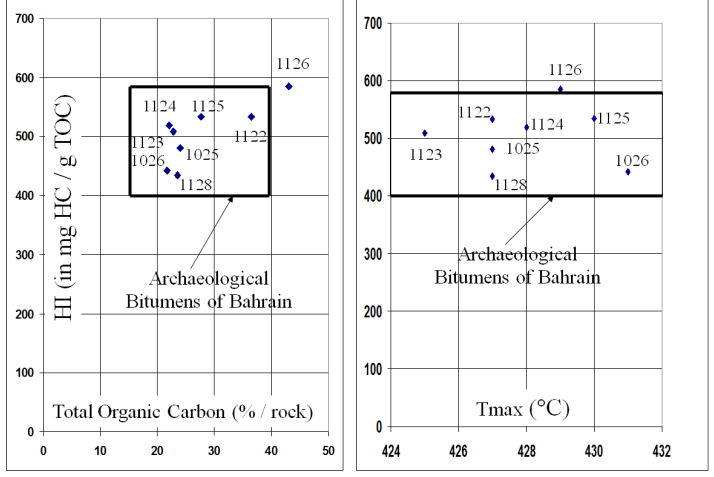

Figure 2 Plot of $\mathrm{HI}$ vs. TOC and $\mathrm{T}_{\max }$.

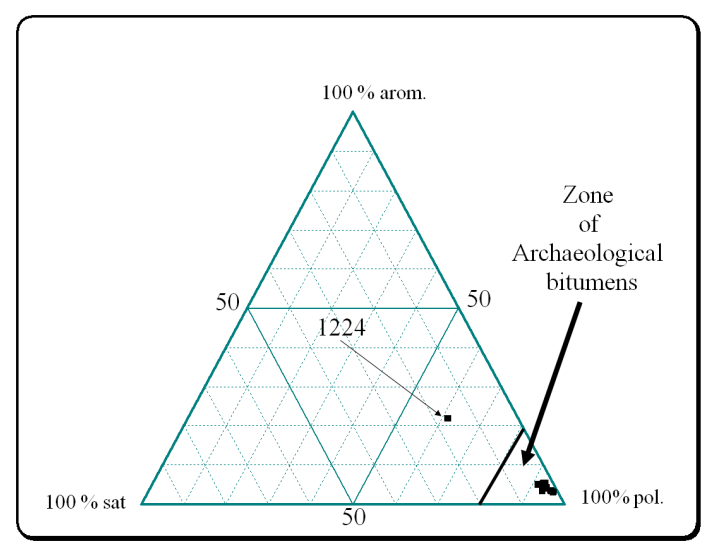

Figure 3 Plot of extract composition in the ternary diagram: \% aromatiques, $\%$ saturates, $\%$ polar.

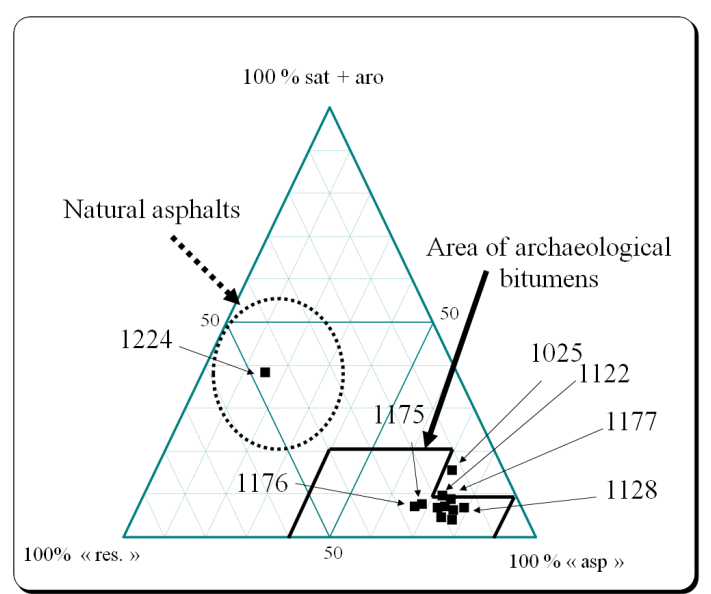

Figure 4 Plot of extract composition in the ternary diagram: \% sat + aro, $\%$ resins, \% apshaltenes.

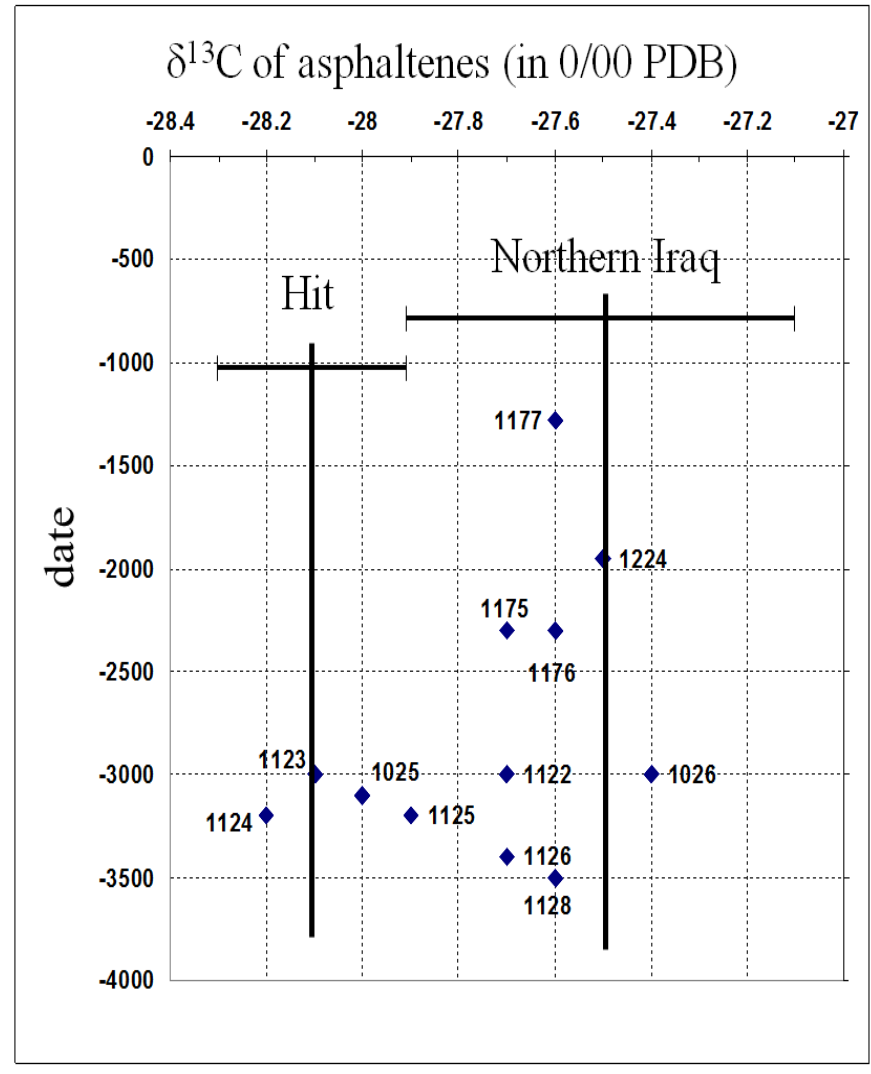

Figure $5 \delta^{13} \mathrm{C}$ of asphaltenes as a function of sample age.

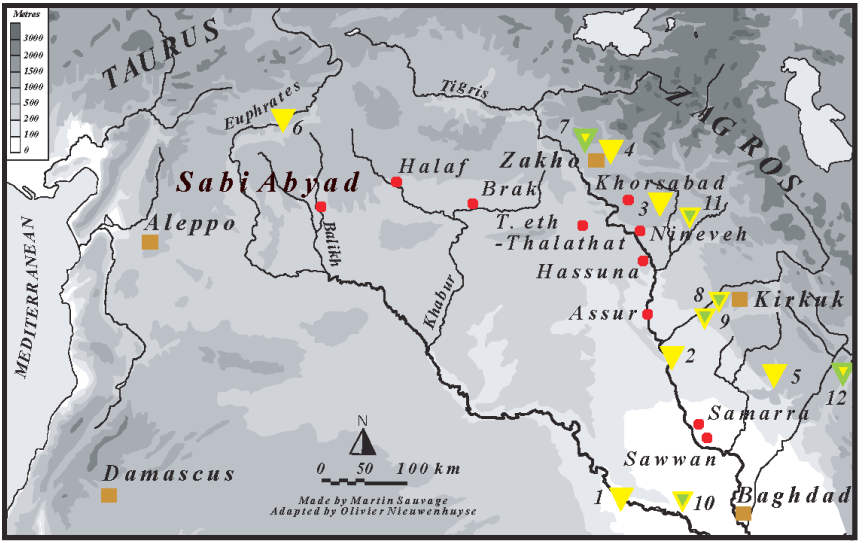

Figure 6 Location of samples used in the study. Significance of numbers: I, Hit; 2, Fattah; 3, Sara, Sati-Qandil Bridge; 4, Zakho; 5, Kifri; 6, Samsat; 7, Kilf oil; 8-9, Kirkuk-Bai Hassan; I0, Fallujah; I I, Damir Dagh; I2,Amam Hassan.

Citation: Connan J, Oates J.The bitumen of Tell Brak from the Middle Uruk (c.3500 BC) to Late Bronze Age (c. 1280 BC): origin and trade routes.J His Arch \& Anthropol Sci. 2018;3(6):756-769. DOI: 10.15406/jhaas.2018.03.00163 

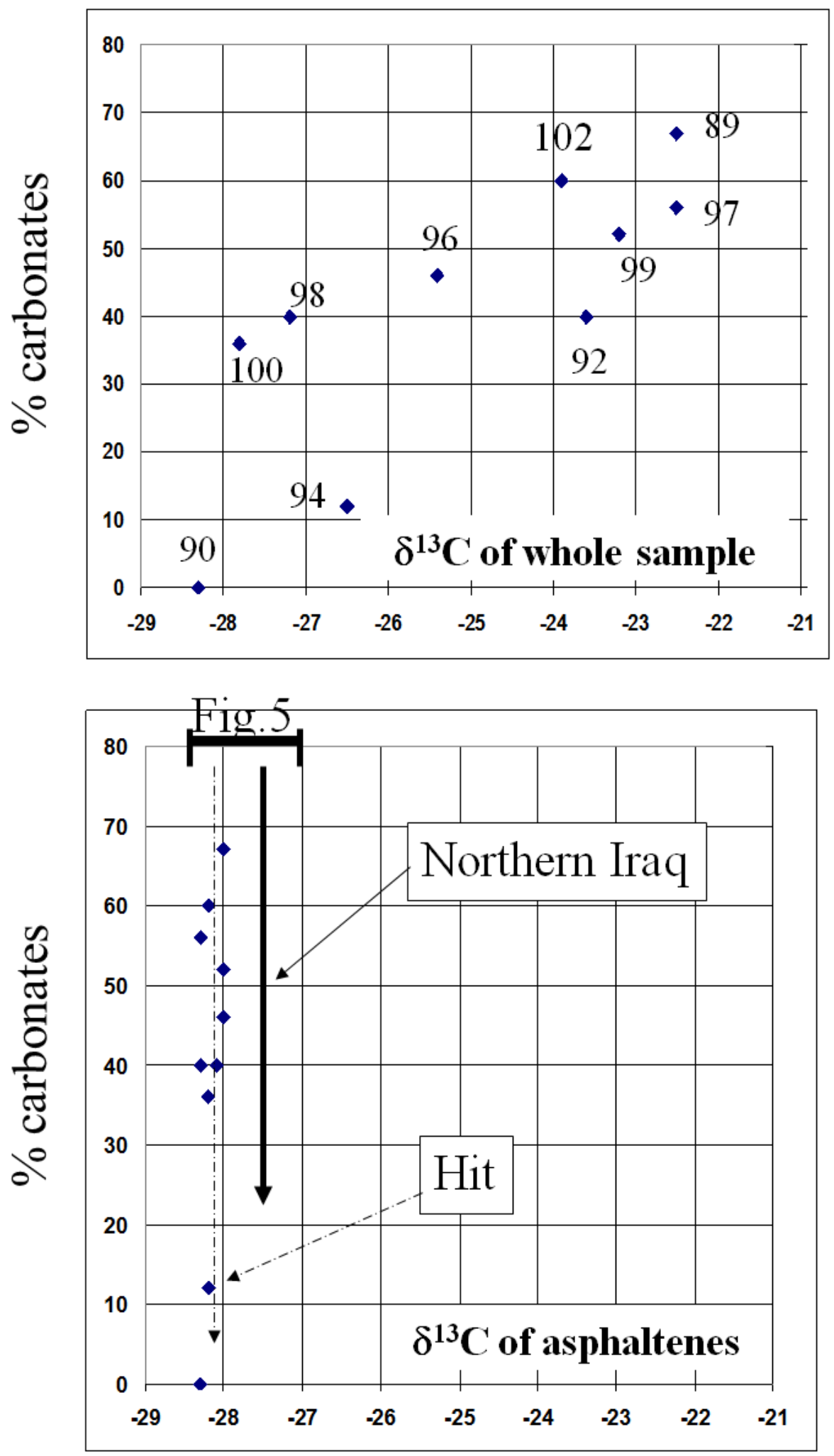

Figure 7 Carbon isotope values of asphaltenes and whole sample as a function of the carbonate content. 




Figure 8 Examples of sterane $(\mathrm{m} / \mathrm{z} 2 \mid 7)$ and terpane $(\mathrm{m} / \mathrm{z} / 91)$.

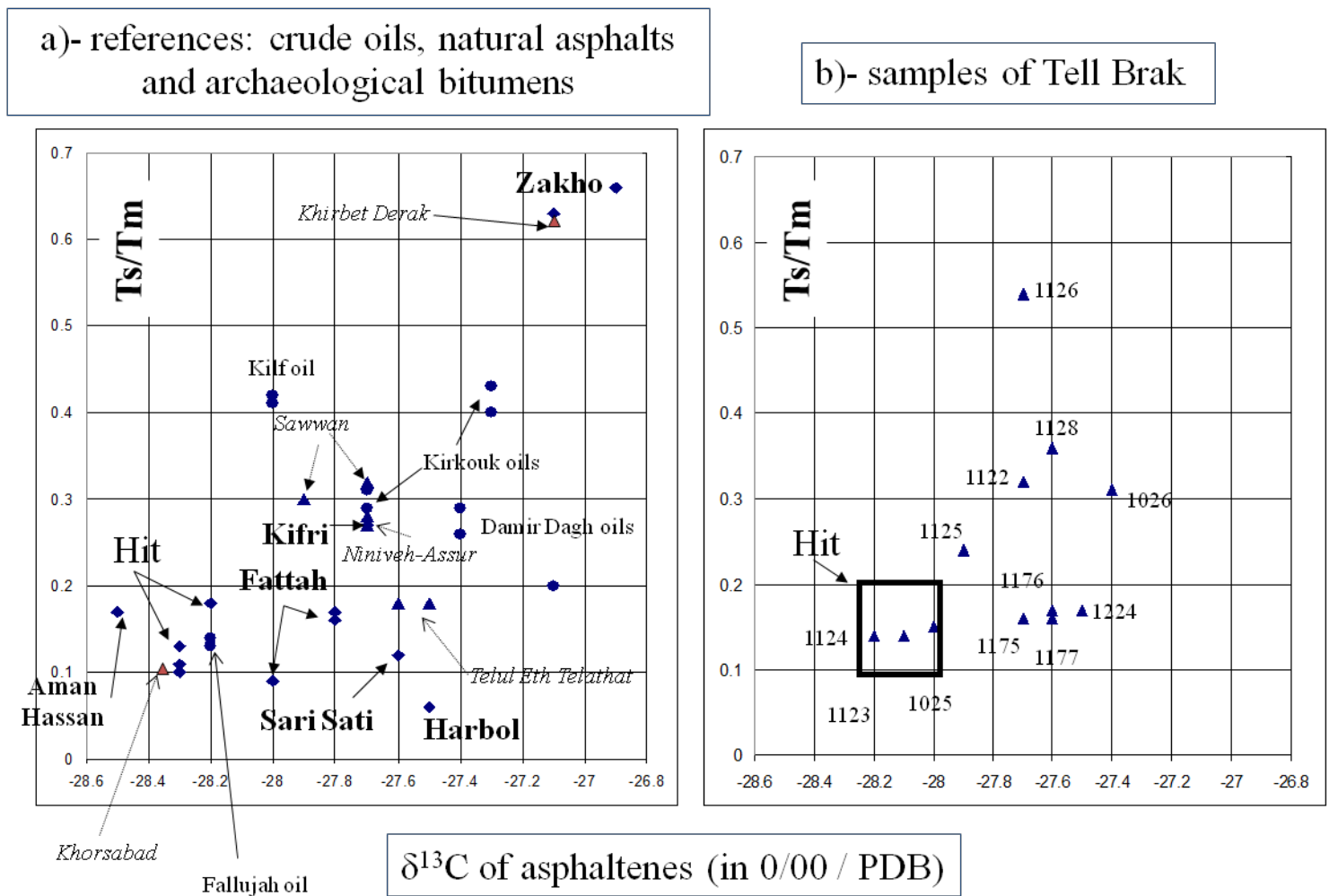

Figure $9 \mathrm{Ts} / \mathrm{Tm}$ vs. $\delta^{13} \mathrm{C}$ of asphaltenes.A. references: crude oils (circle), natural asphalts (diamond) and archaeological bitumens (triangle). B. Samples of Tell Brak. 


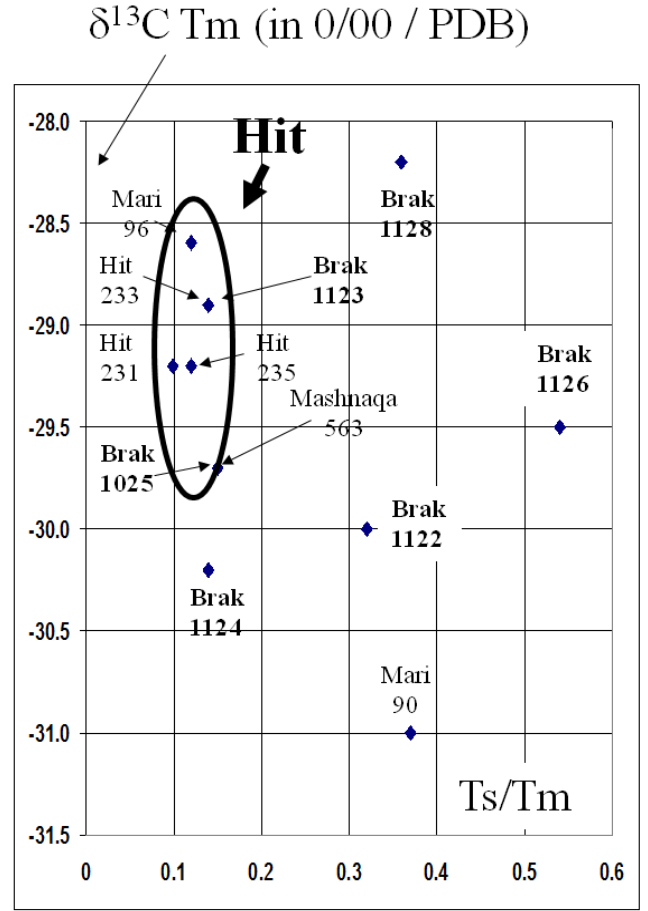

Figure $10 \delta^{13} \mathrm{C}$ of Tm and $\mathrm{C} 3 \mathrm{I} \alpha \beta \mathrm{H}$ opaneR vs. Ts/Tm.

\section{Conclusion}

The geochemical study of 13 archaeological samples from tell Brak has shown that all the samples analysed are true archaeological bitumens as defined previously; i.e. mixtures of natural asphalts or bitumen with various mineral and organic debris. None of them are raw pristine geological bitumens from storages as thought at the beginning of the study. Contents of bitumen, used to prepare archaeological mixtures fall within classical ranges currently used in the Near East and the Gulf. The bitumen import in Tell Brak has been diversified with two main area: Hit along the Euphrates and Northern Iraq. According to present state of the study and the present knowledge of either archaeological bitumens or oil seeps, bitumen seems to have been brought from the Kirkuk-Kifri area and from other places. In particular the same source of bitumen has been used apparently in Telul eth Telathat and Brak. As far as changes through time, we have observed utilisation of bitumen from northern Irak between 3500 and $3400 \mathrm{BC}$, from Hit and northern Irak between 3200 and $3000 \mathrm{BC}$ and solely from northern Iraq between 2300-1280 BC. These information are however deduced from a low number of samples, restricted to 13 samples, and is obviously too restricted to draw general conclusion about trade patterns through time. It only indicates that Brak was at a commercial crossroads receiving raw material from the south along the Rhabour but also from the East through several trade routes to the Mossul-Baghdad areas. ${ }^{24}$

\section{Acknowledgments}

The authors are grateful to all archaeologists who have provides samples for references and to Elf Aquitaine Production for their technical support and the access to a data bank on crude oils. We $\delta^{13} \mathrm{C} \mathrm{C} 31 \alpha \beta$ HopaneR (in 0/00/PDB)

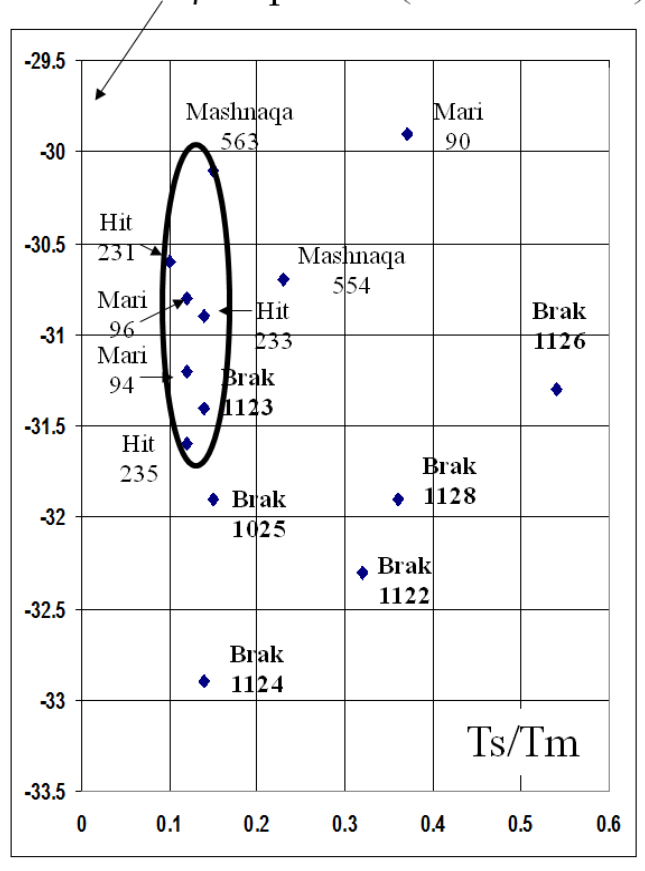

are indebted to the technical staff from the CSTJF of Elf Aquitaine production in Pau who has carried out most of the analyses. In that respect we want to thanks Daniel Dessort, Jean-Bernard Berrut, Béatrice Ruiz, Dominique Duclerc et Yannick Poirier for their efficient technical assistance.

\section{Conflicts of interest}

Author declares that there is no conflicts of interest.

\section{References}

1. Boëda E, Connan J, Dessort D, et al. Bitumen as a hafting material on Middle Palaeolithic artefacts. Nature. 1996;380:336-338.

2. Boëda E, Bonilauri S, Connan J, et al. Middle Palaeolithic bitumen use at Umm el Tlel around 70000 BP. Antiquity. 2008;82(318):853-861.

3. Boëda E, Bonilauri S, Connan J, et al. New evidence for significant use of bitumen in Middle Palaeolithic technical systems at Umm el Tlel (Syria) around 70,000 BP. Paléorient. 2009;34(2) :67-83.

4. Forbes RJ. Bitumen and petroleum in Antiquity. Studies in ancient technology. 2nd edn. Volume 1, Leiden: EJ Brill; 1964. p. 1-123.

5. Marschner RF, Wright HY. Asphalts from Middle Eastern archaeological sites. Archeaological Chemistry 2, Chicago: Advanced Chemical series; 1978. p. $150-171$.

6. Marchner RF, Dufy LJ, Wright HT. Asphalts from ancient town sites in Southern Iran. Paléorient. 1978;4:97-112.

7. Connan J. Use and trade of bitumen in antiquity and prehistory: molecular archaeology reveals secrets of past civilizations. Phil Trans $R$ Soc Lond. 1999;354(1379):33-50. 
8. Connan J. Technical Report on the Comparative, Compositional and Isotopic Analysis of the H3 Bitumen. In: Carter R, Crawford H, editors. Maritime interactions in the Arabian Neolithic: Evidnce from H3, AsSabiayh, an Ubaid-remated site in Kuwait. Brill, Boston and Leiden: American School of Prehistoric Research Monograph Series, Appendix II; 2010. p. 261-287.

9. Connan J, Deschesne O. Le bitume à Suse-Collection du Musée du Louvre. Paris et Pau: Coédition Elf Aquitaine-Réunion des Musées NationauxCollection Monographie; 1996.

10. Connan J, Lombard P, Killick R, et al. The archaeological bitumens of Bahrain from the Early Dilmun period (c.2200 BC) to the sixteen century AD: a problem of sources and trade. Arabian archaeology and epigraphy. 1998;9:141-181.

11. Connan J. Les mélanges bitumineux du Tell d'Akkaz (Koweït). The bituminous mixtures from Tell Akkaz (Kuwait). In: Gachet-Bizollon J, editor, Lyon: Le Tell d'Akkaz au Koweit/Tell Akkaz in Kuwait, TMO 57, Chapitre XV; 2011. p. 339-412.

12. Connan J, Carter R. A geochemical study of bituminous mixtures from Failaka and Umm an-Namel (Kuwait), from the Early Dilmun to the Early Islamic period. Arab arch epig. 2007;18:139-181.

13. Connan J, Deschesne O. Le bitume à Mari. In: Akh Purratim, Margueron JC, Rouault O, Lombard P. editors, Série "Akh Purattim-Les Rives De L'euphrate. Mémoires d'archéologie et d'histoire interdisciplinaires, Maison de L'Orient et de la Méditerranée-Ministère des affaires étrangères, 2007. p. 165-206.

14. Connan J, Carter R, Crawford H, et al. A comparative geochemical study of bituminous boat remains from H3, As-Sabiyah (Kuwait) and RJ-2, Ra's al-Jinz (Oman). Arab arch epig. 2005;16:21-66.

15. Schwartz M, Hollander D, Stein G. Reconstructing Mesopotamian exchange networks in the 4th millenium BC: geochemical and archaeological analyses of bitumen artefacts from Hacinebi Tepe, Turkey. Paléorient 2000;25(1):67-82.
16. Schwartz M, Hollander D. The Uruk expansion as dynamic process: a reconstruction of Middle to Late Uruk exchange patterns from bulk stable isotope analyses of archaeological bitumen. Journal of Archeological Science Reports. 2016;7:884-899.

17. Connan J, Breniquet C, Huot JL. Les objets bituminés de Tell el ‘Oueili : des témoins de la diversité des réseaux d'échanges commerciaux de l'Obeid 0 à l'Uruk récent, in Oueili. Paris: Travaux de 1987 et 1989, ERC; 1996. p. 413-453.

18. Connan J. L'archéologie moléculaire et isotopique: étude géochimique des bitumes, brais et goudrons de bois. In: Miskovsky JC, editor. Géologie de la Préhistoire: Méthodes, Techniques, Applications. Paris: Association pour l'étude de l'environnement géologique de la préhistoire; 2002. p. 1045-1066.

19. Connan J. Quelques secrets des bitumes archéologiques de Mésopotamie révélés par les analyses de géochimie organique pétrolière. Bull Centres Recherches Exploration-Production, Elf Aquitaine. 1988;12(2):759-787.

20. Karhu J. Carbon isotope. In: Marshall CP, Fairbridge RW, editors. Encyclopedia of Geochemistry. Kluwer Academic Publishers; 1999. p. 67-73.

21. Clark ID. Stable isotopes. In: Marshall CP, Fairbridge RW. Encyclopedia of Geochemistry, Kluwer Academic Publishers; 1999. p. 588-592.

22. Peters KE, Moldowan JM. The biomarker guide. New Jersey: Englewood cliffs, Prentice-Hall; 1993.

23. Pascoe EH. Geological notes on Mesopotamia with special reference to occurrences of petroleum. Memoir of the Geological Survey of India. 1922;48:1-90.

24. Connan J, Van de Velde T. An overview of bitumen trade in the Near East from the Neolithic (around $8000 \mathrm{BC}$ ) to the Early Islamic period. Arb arch epig. 2010;21:1-19. 